\author{
Katarzyna Sawicka-Mierzyńska \\ Wydział Filologiczny \\ Uniwersytet w Białymstoku \\ e-mail: ka.sias@wp.pl
}

\title{
Figura Atlantydy w twórczości Miry Łukszy
}

Zielony od pleśni jest dom zapomnienia

(Paul Celan)

Mira Łuksza, rocznik 1958, absolwentka filologii polskiej i rosyjskiej, poetka, prozaiczka, dziennikarka (od 1985 roku pracuje w tygodniku Białorusinów w Polsce "Niwa”), pisze w języku białoruskim i (rzadziej) polskim, wydała zbiory poezji (Zamowa (1993), Jest (1994), Wiersze tutejsze (2003), Zwierzaczki z tutejszej paczki (2009), Pod znakiem Skorpiona (2011), Biały stok (2012) i prozę: Dziki ptak wróbel (1992), Wyspa (1994), Babskie historie (2001), Dziewczynka i chmurka (2006), Historie z tego świata (2008), Życie pozagrobowe $i$ inne (2013).

Z lektury tekstów Łukszy wynika, że jedną z ważnych figur jej twórczości jest topos Atlantydy. Za jego swoistą matrycę uznać można obraz pojawiający się w wierszu Ulica Młynowa, pochodzącym z tomu Biały stok. Liryk ten zostaje tu obrany za punkt wyjścia nie tyle z racji chronologii (tomik opublikowano 2012 roku), co ze względu na obecność właściwie wszystkich elementów, znaczeń, konotacji, jakie łączą się z Atlantydą w wyobraźni Łukszy.

W tych dniach ostatnich atlantyda Młynowej zachłysnęła się papierowo-asfaltowym tsunami.

Wiekowe byliny zapamiętale zaciskają korzeń, jasnota biała głuchnie pod kamienną skórą. Milczę i ja, jak pod wodą wstrzymując oddech, idąc po innej ulicy w kierunku zdeptanego miejsca tych, za których żyje w tym odcinku światła ${ }^{1}$.

1 M. Łuksza, Biały stok, Warszawa 2012, s. 11. 
Młynowa, zlokalizowana niemal w ścisłym centrum, zamieszkiwana przed wojną przez Żydów (należy do najbardziej znanych ulic Chanajek, dawnej żydowskiej dzielnicy) jest jedną z najintensywniej zagospodarowywanych (zwłaszcza po 1989 roku), niestety bez troski o relikty dawnej, drewnianej zabudowy czy architektoniczny ład ulic Białegostoku. Tuż obok niej wznosi się miedzy innymi gmach Opery i Filharmonii Podlaskiej - Europejskiego Centrum Sztuki. W tchnącym atmosferą apokalipsy („dni ostatnie”) wierszu Młynowa staje się metonimią dawnego miasta, częścią zatopionej pod betonem nowych budynków, asfaltu i - co ważne - papieru, Atlantydy. Jak łatwo zauważyć, Łuksza buduje tu zaksjologizowaną, binarną opozycję: podwodny świat, symbolizujący przeszłość, rośliny (w domyśle także drewno, z którego zbudowane były domy na Młynowej), z jakimi utożsamia się podmiot, przeciwstawione zostają kamieniom, papierowi (za nim mogą się kryć dekrety, architektoniczne projekty, mowa władzy, mediów, ale też historia) oraz agresywnej nowoczesności.

Przeszłość, pamięć o niej i rośliny pojawiają się także w wierszu Ulica Lipowa (z tego samego tomu), kończącym się słowami:

Przy soborze drzew nie ma, lecz korzeń pamięta. Na pamięć idę z nimi, za nimi ślad mój ciepły wiatr zwiewa, przestwór się skamienia. Jeszcze chwila. Spamiętasz? Czy coś bardziej zaboli, jak wyrwanie $\mathrm{z}$ albumu pamięci twoich oczu i ust ${ }^{2}$.

I w liryku Morze:

Sen się śni. Jesień. Pola pod Puszczą. [...]

Niżej traw moja dusza, lecz nad horyzont widzenie; tam nie ma mnie, jestem. Lipa, co rośnie sto lat. Maleńka była (i we śnie pamiętam, a to pamięć prababki, co w Sybir z wszystkimi nie poszła, przed najeźdźcą, bo jak umierać, to tylko na swoim), okrągłą koronę twardo trzyma na karku. [... $]^{3}$

Biały stok, zbudowany niczym auto/bio/geograficzny atlas Miry Łukszy, prowadzi czytelników także do innych niż tytułowe miasto, ważnych dla autorki miejsc. Jednym $\mathrm{z}$ nich jest podwodny świat Bondar:

\footnotetext{
2 Tamże, s. 17.

3 Tamże, s. 33.
} 
Dom zalany wodą nie może oddychać.

Jabłoń, choć słońce się przebija aż do dna jeziora, ni liśćmi, ni owocem nie oddarzy światła.

Budy bezpieskie, płoty bezkocie, bramki donikąd zardzewiałym zawiasem kiwają jak palcem na ryby.

Z Bud zalanych Michał Łuksza, ze sławnej orkiestry,

majsterklepka, radiowiec i podglądacz świata,

przeniesiony do Bondar, na wysokie piętra osiedla umarłych,

z pamięcią uwiecznioną w głowie i na zdjęciach,

z okien krzyczy muzyką, ponad blokowisko.

I w kosmos wysyła radiowe wołania, do tych co są jeszcze ${ }^{4}$.

Poetka nawiązuje tu do niezwykle ważnego na lokalną skalę wydarzenia, jakim była ukończona w 1990, a rozpoczęta w 1977 roku budowa Zalewu Siemianówka, dziś jednej z atrakcji turystycznych Podlasia. Na jej potrzeby wykupiono i wywłaszczono ok. 300 gospodarstw z 8 wsi, zamieszkiwanych przez ludność prawosławną, którą ulokowano w wybudowanym w tym celu osiedlach w Michałowie oraz tytułowych Bondarach. Tego tematu dotyczy również napisane $\mathrm{w}$ języku białoruskim opowiadanie Bııcna [Wyspa] z 1994 roku - rozpoczyna je obraz starego człowieka, który płacze stojąc na skrzyżowaniu głównych ulic Białegostoku, tuż przy pomniku Józefa Piłsudskiego. Wpada na niego siedemnastolatek Pryszcz: chłopak biegnie na autobus, bo jedzie, jak co roku latem, z przyjaciółmi na biwak, tyle że w bardzo specyficzne miejsce - jest nim wyspa na Siemianówce. Oto fragment-parafraza w tłumaczeniu filologicznym:

Na tym jeziorze była ich wyspa, porosła starymi sadami jabłoni, krzywymi wiśniami i dziką różą. Dookoła podmurówki, na której kiedyś stała chata i na szczerbatych ruinach kaflowych pieców ścielił się rabarbar, cebula-zimówka, wybujały wieczny czosnek, którego nie niszczył największy lutowy mróz, koper, dzika marchew [...]. Była tu kiedyś stara, więcej niż dwustuletnia wioska Budy, zamożna, solidna. Woda pokryła wszystko. Gdzieniegdzie zostały wyspy-piersi. Dopływali chłopcy na taki swój kawałek starą drewnianą łódką nieboszczyka Jaśka Łukszy ${ }^{5}$.

W innym opowiadaniu - Стражнік старое сьцежкі [Strażnik starej ścieżki] - pod wodą znajdzie się dąb. Jak w wielu obrazkach Łukszy, ilustrujących erozję wiejskiej społeczności, mamy tu rozbitą rodzinę - dziadka, do którego ucieka wnuczka, bo mama jest gdzieś daleko i tylko przysyła ojcu pieniądze, a jej samej zabawki. Niestety po śmierci babci starszy człowiek

\footnotetext{
4 Tamże, s. 24.

5 M. Łuksza, Bııcna, w: tejże, Bııcna, Białystok 1994, s. 16-17 [przeł. - K.S.M.].
} 
wiąże się z kobietą, która nie toleruje obecności Lucynki w domu. Zrozpaczona dziewczynka kryje się $\mathrm{w}$ lesie, gdzie dziadek znajduje ją niemal umierającą. Jedynym świadkiem tych wydarzeń jest dąb, który przez wieki spoczywał pod wodą, a teraz robotnicy pracujący przy regulacji rzeki wydobyli go i rzucili niedbale na pobocze tytułowej ścieżki. Opowiadanie ma klamrową konstrukcję - obraz dębu rozpoczyna je i kończy, a narrator dodaje od siebie retoryczne pytanie: „Kto jeszcze wie gdzie była Białka, gdzie w tych miejscach straszyło do wojny i później, gdzie stała żydowska karczma, co się potem stało, a kto nie wie - to i po co mu się tego dowiadywać, pytać?..." 6

Kolejny - choć nie ostatni, który można by przywołać - obraz podwodnego świata (najbardziej nieoczywisty i, w perspektywie tych rozważań, intrygujący) pojawia się $\mathrm{w}$ opowiadaniu Прот, народжань у верасьні [Prot, urodzony we wrześniu]. Tytułowy bohater przyjeżdża do Białegostoku z Belgii przed Nowym Rokiem i wędruje wraz z przyjacielem po mieście w poszukiwaniu innych znajomych i miejsca, gdzie mogliby się wspólnie napić. Przeszkadzają mu w tym buty - glany, obcierające stopy do krwi. W mieszkaniu kolegi, którego ratują przed próbą samobójczą, Prot:

Znowu odczuł mocny ból w lewej nodze. Zesztywniałymi palcami długo mocował się ze sznurówką, rozginał miękką, bydlęcą skórę. Skarpetka była zesztywniała od zakrzepłej, brunatnej krwi.

Pokuśtykał na pięcie do kuchni. Chłodna woda piekła ogniem. Patrzył w nią. Spływała rurami do wnętrza domu, ściekała do rzek, podziemnych żył miasta, odchodziła do rzeki wiecznej.

I znów wracała ${ }^{7}$.

Czyli, na razie dosłownie rzecz ujmując, krew z obmywanej białoruskiej stopy wnika do podziemnych wód (żył, krwiobiegu) miasta, potem do wiecznej rzeki, i znowu wraca do kranów, które poją jego mieszkańców.

$\mathrm{Na}$ koniec tej sekwencji obrazów-cytatów, warto przywołać deklarację Miry Łukszy, zamieszczoną jako wstęp do zbioru Wiersze tutejsze z 2003 roku:

Jesteśmy stąd. Z Wielkiego Księstwa i Podlasia. Lacy, Lićwiny, Rusiny. Bezmieżne pogranicze. Jesteśmy z mojej duszy. Jesteśmy stąd. Wielkie Księstwo jest wciąż. I ci, których nie ma, [...] rataje Bogiem dani na ratunek duszy, na zaoranie niwy podlaskiej. Poczciwi Mikołaje, wojowniczy Michałowie nie z niebiańskich rot. Zbieracze pieśni zapomnianych, które się w sercu oddźwięczą i odwdzięczą. Mocni sterani i cisi. Wielcy nad łąkami, które zalewa niepamięć.

\footnotetext{
6 M. Łuksza, Стражнік старое съцежкі, w: tejże, Bъıсnа, s. 31 [przeł. - K.S.M.].
}

7 M. Łuksza, Прот, народжаны ц̆ верасъні, w: tejże, Bъıсnа, s. 60. 
Nie ci „tutejsi”, bojący się własnego cienia, nacji i Boga sławionego własnym słowem. Z pola i lasu, nad którym jest On, nad naszym miejscem. Cisówka. Bondary. Narew. Hajnówka. Bielsk. Huszczewina. Michałowo. Krzywa. Kotłówka. Jaryłówka. Ryboły. Malinniki. Rybaki. Topolany. Gródek. Borowe. Tanica. Mikłaszewo. Morze. Zelwa. Waliły. Bondary. Saki. Sokółka. Jaryłówka. Romanowo... Białystok. Krynki... Miejsca puściejące. Nie opuszczone ${ }^{8}$.

Jak zinterpretować to przenikające wyobraźnię Łukszy połączenie przeszłości i pamięci/zapominania, białoruskiej tożsamości, Wielkiego Księstwa Litewskiego, motywu podziemnych wód i towarzyszącej ludziom bądź ruinom przyrody? Dlaczego zmaterializowały się w takim, a nie innym obrazie, który, wychodząc od cytowanego na początku wiersza, określić można mianem figury Atlantydy? Czy to w ogóle ma jakieś głębsze znaczenie? A może jest po prostu bardziej lub mniej oryginalną realizacją starego jak Platon toposu? W jaki sposób, zarówno sam obraz Atlantydy, jak służące jego interpretacji narzędzia, np. z zakresu pamięciologii czy posthumanizmu, zostają zmodyfikowane przez białoruskość poetki i specyfikę tych ziem, ich pograniczny charakter? Jest to przecież ewidentnie Atlantyda podlaska. Jak - ale to już temat na osobną rozprawę - ma się ona do wykreowanej na początku lat 90. XX wieku przez Borussię „Atlantydy Północy”?

Według badaczy fenomenu pamięci, nie tylko przedstawia się ją (co naturalne zwłaszcza w przypadku literatury, a jeszcze bardziej - poezji, jak u Łukszy) za pomocą metafor, ale też trudno ją bez ich użycia definiować. Jak zauważa Aleida Assmann, „oferują dostęp do pamięci, która opiera się dosłownemu opisowi"9, a „sztuka pamięci - zdaniem Magdaleny Saryusz-Wolskiej - jest zarazem sztuką przestrzeni i obrazu” ${ }^{10}$. „Metaforyczność pamięci nie jest tylko kwestią jej symbolicznych przedstawień. Przeciwnie: leży także u podłoża samego pojęcia pamięci zbiorowej" ${ }^{11}$. Günter Butzer, choć ustosunkowuje się polemicznie wobec tezy, „że metafory pamięci mogą konstytuować przedmiot, którego dotyczą", wieńczy swoje rozważania na temat metaforyki pamięci stwierdzeniem, iż czynią to modele opisu właściwe danej kulturze ${ }^{12}$. Reasumując: wybór obrazowania służącego

8 M. Łuksza, Wiersze tutejsze, Białystok 2003, s. 3.

9 A. Assmann, Metafory, modele i media pamięci, przeł. Zofia Dziewanowska-Stefańczyk, w: tejże, Między historia a pamięcia. Antologia, red. M. Saryusz-Wolska, Warszawa 2013, s. 90-91.

10 M. Saryusz-Wolska, Spotkania czasu z miejscem. Studia o pamięci i miastach, Warszawa 2011, s. 71 .

11 Tamże, s. 75.

12 G. Butzer, Metaforyka pamięci, przeł. M. Saryusz-Wolska, w: Pamięć zbiorowa i kulturowa. Perspektywa niemiecka, red. M. Saryusz-Wolska, Kraków 2009, s. 189, 206. 
opisowi pamięci determinuje jej rozumienie, przypisywaną rolę, strukturę, mechanizmy działania. Zarówno na procesy pamięci, jak też na rodzaj obrazowania wpływa z kolei konkretny krajobraz, miejsce. Jak zauważa Elżbieta Rybicka:

miejsca nie pełnią tylko funkcji lokalizacyjnej dla wspomnień, nie są tylko „magazynami", z których ,ja" autobiograficzne wydobywa przeszłość. Pełnią często funkcję stymulacyjną, sprawczą, aktywizując pamięć autobiograficzną i pamięć cielesną ${ }^{13}$.

Warte przytoczenia w tym kontekście - także geograficznym - wydają się refleksje Simona Schama, stanowiące prolog do książki Landscape and memory, gdzie opisuje on swoje wrażenia $\mathrm{z}$ pobytu $\mathrm{w}$ powiecie sejneńskim, na północnym wschodzie województwa podlaskiego, gdy zobaczył kopiec i krzyż w Gibach, upamiętniające ofiary NKWD z 1945 r. Dokładnie z tego miejsca rozciąga się widok na przepiękny pejzaż, który kojarzy się Schamowi z Mickiewiczowskimi strofami, a przez rozważania o żydowskim pochodzeniu autora Pana Tadeusza wiedzie do namysłu nad własnymi przodkami, pochodzącymi właśnie z tych ziem.

Trzeba mi było aż kopca w Gibach, by zrozumieć sens określenia „krajobraz i pamięć". Na pierwszy rzut oka, gdy po raz pierwszy mignął mi przez szybę "starożytnego" mercedesa, wyglądał nijako, ot porośnięty krzakami pagórek, na którym ktoś umieścił prowizoryczny krzyż - następny zaściankowy fetysz w miejscu po dziś dzień otoczonym pobożnym szacunkiem. Coś mnie jednak w nim uderzyło, poczułem się nieswojo, nie potrafiłem nie spojrzeć ponownie. Zawróciliśmy samochód.

Jechaliśmy przez północno-wschodni zakątek Polski, miejsce, gdzie granice państw robią posłuszne to „naprzód marsz" to „w tył zwrot” nie znoszącym sprzeciwu rozkazom historii. [...]

W oddali, zajmując wschodni horyzont, ciemniała niewzruszenie ściana lasu, lasu najbardziej starożytnego w Europie.

Musiałem aż do Polski przyjechać, by zobaczyć ten las. Chociaż dokładnie... nie byłem pewien, co chciałem zobaczyć. Historyków w przeszłość zawsze prowadzi tekst, czasami obraz, czyli obiekty bezpiecznie ukryte pod gablotką akademickiej konwencji [...].

Oto ziemia, za którą mieszkańcy Gib zginęli, i z którą się, w formie poświęconego im kopca, połączyli. Pamięć o nich przyjęła obecnie formę samego krajobrazu. Metafora stała się rzeczywistością, nieobecność stała się obecnością ${ }^{14}$.

13 E. Rybicka, Geopoetyka. Przestrzeń i miejsce we wspótczesnych teoriach i praktykach literackich, Kraków 2014, s. 287.

14 S. Schama, Krajobraz i pamięć. Okrężna droga, „Krasnogruda” 2000, nr 11, s. 8-9. 
„Pamięć o nich przybrała formę samego krajobrazu” - tak mogłaby powiedzieć Mira Łuksza, wpatrując się w spokojne wody Siemianówki, gdzie metafora „zatopionego królestwa” stała się rzeczywistością. W przypadku Łukszy zaciera się też właściwie podział na metafory pamięci zbiorowej i obrazy przypisane indywidualnym doświadczeniom. Pisarze mniejszościowi wykazują bowiem, na co zwraca uwagę Helena Duć-Fajfer,

ambiwalencję dążeń w stosunku do utrwalania przeszłości w zapisie tekstowym. Dążność do opisania swego życia jako świadectwa czy świadczenie o przeszłości i "prawdzie” konkuruje tu z potrzebą stworzenia analogicznej do posiadanej przez centra historii narodowej ${ }^{15}$.

Mówiąc jeszcze inaczej: własna, indywidualna przeszłość już na etapie formułowania wspomnienia nabiera cech przeszłości reprezentatywnej dla zagrożonej społeczności, staje się jej metonimiczną wykładnią, gwarantem, obietnicą. Kształtowana w ten sposób pamięć nabiera tym samym pewnych cech postpamięci. Według Marianne Hirsch:

Postpamięć charakteryzuje doświadczenie tych, którzy dorastali $\mathrm{w}$ środowisku zdominowanym przez narracje wywodzące się sprzed ich narodzin. Ich własne, spóźnione historie ulegają zniesieniu przez historie poprzedniego pokolenia ukształtowane przez doświadczenia traumatyczne, którego [sic] nie sposób ani zrozumieć, ani przetworzyćc ${ }^{16}$.

Tak będzie m.in. w wierszu Romanowo:

Idzie maleńka Luba, niesie brata na głowie.

Woda ust jej dotyka. Idzie się lekko po rzece.

[niesie brata Michałka z Syberii do domu, do Romanowa - dop. K.S.M.]

Gdy siedzimy na murze w Białymstoku, nad Białą,

ja i Olek, studenci, o teatrze mówimy,

to widzimy nie widząc - idą dzieci po wodzie,

niesie brata do domu przez ruiny wszechświata.

I poznaliśmy siebie. Olek, wnuk Michasiowy,

a ja - Luby tej wnuczka, rodem co z Romanowa ${ }^{17}$.

oraz we wszystkich utworach dotyczących zalanych wsi czy historii Białegostoku. Dochodzi do sytuacji, w których narratorka bardziej utożsamia się z utraconą, niekoniecznie własną, przeszłością niż z czasem teraźniejszym.

15 H. Duć-Fajfer, Pomiędzy bukwą a literą. Wspótczesna literatura mniejszości białoruskiej, ukraińskiej i łemkowskiej w Polsce, Kraków 2012, s. 14.

16 M. Hirsch, Żałoba i postpamięć, przeł. K. Bojarska, w: Teoria wiedzy o przeszłości na tle wspótczesnej humanistyki, red. E. Domańska, Poznań 2010, s. 254.

17 M. Łuksza, Biaty stok, s. 39. 
Ujmując rzecz jeszcze wyraziściej: autorka, podmiot, narratorka tych wierszy i opowiadań zawsze będzie nie tylko Mirą Łukszą, ale reprezentantką narodu w stanie zagrożenia. Za sprawą interioryzacji doświadczanych przestrzeni, gdy - jak to ujmuje Rybicka - „«ja» autobiograficzne staje się nosicielem uwewnętrznionych miejsc" ${ }^{\prime 18}$, poetka nosi też $\mathrm{w}$ sobie/ze sobą białoruskie krajobrazy, z zaklętą w nich historią („To miejsce idzie ze mną, dokądkolwiek ruszę" - tak brzmi pierwszy wers pierwszego wiersza $z$ tomu Biały stok).

Wydaje się też, w świetle uwag Duć-Fajfer, że zaciera się tu eksponowana przez Ewę Domańską różnica między pamięcią a historią:

Najważniejszy stał się fakt, że pamięć nie jest historią. [...] Podczas gdy historię określano jako instrument nacisku i identyfikowano z modernizmem, państwem, imperializmem, scjentyzmem i antropocentryzmem, pamięć traktowano jako uzdrawiające lekarstwo i narzędzie odkupienia, odnosząc ją do postmodernizmu i „wyzwolenia” grup, których [sic!] historia pozbawiła głosu. [...] Pamięć stała się użytecznym narzędziem analizy odmienności i różnic [...].

Nietrudno zauważyć, iż terapeutyczna hermeneutyka pamięci oraz quasi-religijny dyskurs niewyrażalnego kształtują zupełnie inny styl myślenia, badania i pisania o przeszłości, którego słownik wypełniony jest tak obcymi historii naukowej pojęciami, jak: wstyd, wina, odkupienie, zadośćuczynienie, wybaczenie, ukojenie, wypełnienie czy katharsis. Pamięć wydaje się rodzajem „kulturowej religijności”, sposobem na „zaczarowanie” naszego poczucia przeszłości ${ }^{19}$.

Tutaj historia pozostaje bowiem ukrytym autorytetem, przedmiotem tęsknot i ambicji, stąd wywodzi się, jak sądzę, ciągłe wygrywanie napięć między tymi dwoma dyskursami i poetykami - pamięci oraz historii, ich nieustające wzajemne przyciąganie i odpychanie. Wszystkie wymienione przez Domańską cechy, przypisywane pamięci - wstyd, wina, odkupienie, zadośćuczynienie itd. - znajdziemy w białoruskich zapisach historycznych, powstających na Podlasiu (celuje w tym Sokrat Janowicz, jako autor eseistycznej, co prawda, ale jednak o ambicjach badawczo-porządkujących, prozy Białoruś, Białoruś). Oscylują one nawet, podobnie jak w przypadku recepcji bieżeństwa ${ }^{20}, \mathrm{w}$ stronę mitologizacji. Generuje to, sygnalizowane przez Paula

\footnotetext{
18 E. Rybicka, Geopoetyka, s. 287.

19 E. Domańska, Wprowadzenie, w: Pamięć, etyka i historia. Anglo-amerykańska teoria historiografii lat dziewięćdziesiątych (Antologia przektadów), red. E. Domańska, wyd. 2, Poznań 2006, s. 16, 17.

20 Mianem „bieżeństwa” określa ucieczkę ludności chłopskiej zamieszkującej m.in. zachodnie gubernie Rosji (należało do nich wówczas dzisiejsze pogranicze polsko-białoruskie), która miała miejsce w 1915 r. Chłopi uciekali nakłaniani przez cofającą się armię rosyjską - tym samym chciano odciąć zaplecze zbliżającemu się niemieckiemu frontowi. Szacuje się, że w głąb
} 
Ricoeura, a uzasadnione stygmatyzacją jako jednym z wyznaczników mniejszościowej tożsamości, ryzyko nadużywania pamięci. Jak pisze Elżbieta Czykwin, „poczucie niezawinionej krzywdy, zapisane w przeszłej legendzie relacji z większością, staje się dominującym doświadczeniem reprezentantów mniejszości" ${ }^{21}$. Dalej czytamy:

Jakkolwiek interpretacja wspólnych, historycznych wydarzeń dotyczących Polski i autochtonicznej mniejszości często różnicuje opinie przedstawicieli mniejszości i większości w tych kwestiach, to różnice te nie tyle dotyczą, moim zdaniem, opinii czy interpretacji, ale emocjonalnych znaczeń, przede wszystkim poczucia krzywdy i jej uzasadnień.

W tym rozumieniu szereg interpretacji faktów historycznych stanowi racjonalizację emocjonalnej potrzeby utrzymania dobrego mniemania o sobie, w której centralne jest poczucie własnej krzywdy ${ }^{22}$.

Ricoeur ujmuje to jako „nadużycie” głosu ofiar:

Idea długu nierozerwalnie wiąże się z ideą dziedzictwa. Jesteśmy dłużni wobec tych, którzy nas poprzedzali w tym, czym jesteśmy.

[...] pośród tych wszystkich innych, wobec których jesteśmy zadłużeni, pierwszeństwo, ze względów moralnych, przyznajemy ofiarom. Todorov ostrzegał jednak przed skłonnością do uznawania się za ofiarę i ustawicznego domagania się zadośćuczynienia. I miał rację. Ofiara, o którą tutaj chodzi, to ofiara-inny, ktoś inny niż my.

Skoro takie jest uprawomocnienie obowiązku pamiętania jako obowiązku sprawiedliwości, to jakim sposobem na właściwym użyciu krzewi się nadużycie? Może chodzić tylko o nadużycia w posługiwaniu się ideą sprawiedliwości. To właśnie w tej sferze pewne roszczenia wzbudzone przez namiętne wspomnienia, wspomnienia zranien, roszczenia względem ogólniejszych i ważniejszych celów historii, zabarwiają ogłoszenie obowiązku pamiętania tonem groźby zapowiadającej karę, która najwyraźniej dochodzi do głosu w zachętach do bezwzględnego upamiętniania ${ }^{23}$.

Rosji wyjechało wtedy od 3 do 6 milionów ludzi, jedna trzecia miała nie przeżyć tego exodusu. Uchodźcy zaczęli wracać do Polski po rewolucji październikowej, trwało to aż do $1922 \mathrm{r}$. Istnieje strona internetowa, stworzona przez Anetę Prymakę-Oniszk, na której rozpoczęto dokumentowanie wspomnień o „bieżeństwie” (biezenstwo.pl). W 2015 roku ukazała się książka Bieżeństwo. Droga i powroty. 1915-1922, autorstwa Doroteusza Fionika, zawierająca, poza wspomnieniami bieżeńców i ich potomków, liczne fotografie i materiały dokumentacyjne. Zarówno sam sposób prowadzenia narracji, jak też wypowiedzi Fionika podczas spotkań promujących książkę wskazują na to, że historia bieżeńców mogłaby, jego zdaniem, pełnić funkcję podlaskiego (i/lub białoruskiego) mitu założycielskiego.

21 E. Czykwin, Białoruska mniejszość narodowa jako grupa stygmatyzowana, Białystok 2000, s. 9.

22 Tamże, s. 171.

23 P. Ricoeur, Pamięć, historia, zapomnienie, przeł. J. Margański, Kraków 2006, s. 117-118. 
Oczywiście stwierdzenie Ricoeura o istotności „ogólniejszych i ważniejszych celów historii", którym mają się podporządkować partykularne interesy, brzmi dość kolonialnie, niemniej jednak jego intuicja dotycząca potencjalnych nadużyć pamięci, uniemożliwiających "pracę historii”, wydaje się słuszna. Za przykład takiego szkodliwego nadużycia służyć może reportaż Marcina Kąckiego Białystok. Biała siła, czarna pamięć (Wołowiec 2015). Nie chcę bynajmniej sugerować, że tego typu nadużyć dopuszcza się Mira Łuksza, na pewno jednak jej twórczość podszyta jest, tak jak dorobek innych podlaskich Białorusinów, wiktymologiczną melancholią (jeśli mogę użyć takiego określenia), która determinuje obraz dawnego i obecnego świata.

Wszystko to ma wpływ na wybór takiej, a nie innej metaforyki, takich, a nie innych przestrzeni reprezentujących przeszłość. Oczywiście, jak sygnalizowałam wcześniej, sięgnięcie przez Łukszę po figurę Atlantydy ma swoje uzasadnienie w historyczno-krajobrazowym konkrecie - zalanych wodą sztucznego Jeziora Siemianówka wsi, warto jednak przeanalizować konsekwencje użycia tego toposu dla pracy pamięci.

Istotne wskazówki zawiera już platoński pierwowzór. W dialogu Kritias, gdzie pojawia się obraz zatopionej krainy, poprzedza go rozmowa o pamięci i historii, z której wynika, że „mitologia i badanie przeszłości” należą do państw, zaś

pokolenie, które ocalało [po tubylcach osadzonych na tych ziemiach przez Atenę i Hefajstosa - dop. K.S.M.] [...] zostawało gdzieś po górach i niepiśmienne znało tylko ze słyszenia imiona władców tej ziemi i do tego słyszało coś niecoś o ich dziełach. Więc oni te imiona chętnie nadawali swoim dzieciom, a dzielności i praw przodków nie znali; krążyły między nimi o tym tylko jakieś ciemnie wieści ${ }^{24}$.

„Niedostatek" sprawiał, że skupiali się oni wyłącznie na aktualnych problemach, nie troszcząc się o przeszłość. Opis ten niemal idealnie oddaje diagnozę stanu świadomości historycznej Białorusinów, sformułowaną i rozpowszechnianą w wielu wypowiedziach przez Sokrata Janowicza, którego Mira Łuksza (jak szereg podlaskich Białorusinów zresztą) uznaje za swego patrona.

Atlantyda naprowadza nas więc na niezbywalny związek pamięci i zapominania oraz sugeruje, że do pamięci należy dojrzeć - stanowi ona luksus wymagający cywilizacyjnego zaplecza (państwo i jego instytucje, w tym nauka, archiwa, muzea) oraz materialnego komfortu. Wtedy prawdopodobnie

${ }^{24}$ Platon, Kritias, przeł. W. Witwicki, http://libertarianin.org/Ebooks/Platon/Platon-Kritias. pdf [dostęp 16.06.2016]. 
pamięć staje się historią. Ci, dla których, jak to dosadnie określał Janowicz, najważniejszym autorytetem jest pełny brzuch, nie troszczą się o swoje dziedzictwo, przeciwnie, wstydzą się go i chcą przed nim uciec.

Ten fragment dialogu Platona kieruje nas również w stronę pamięci utajonej, określiłabym ją mianem „przetrwalnikowej”, której symbolicznym atrybutem są też, tak często występujące w cytowanych utworach Łukszy, wody podziemne. Analizując różne typy metafor pamięci, Aleida Assmann wyróżnia takie, "które stawiają utajenie na pierwszym miejscu. By wyjaśnić ten termin, należy rozróżnić dwie formy zapominania: jedną, która jest siłą siejącą rozkład i zniszczenie, drugą o charakterze konserwującym. Utajenie [...] przynależy do drugiej kategorii lub do tego, co F.C. Jung nazywa «konserwującym zapominaniem» ${ }^{25 "}$. Bogaty świat podziemny tej twórczości, to, co pod wodą, poniżej traw, pod asfaltem, byłby zatem sposobem na przetrwanie przeszłości poza oficjalną, historyczną, większościową narracją, poza „papierem" - podręcznikami, archiwami, nawet kulturą. Nie ma soboru, jak czytaliśmy, nie ma już nawet drzew, lecz korzeń pamięta, co więcej, można iść za nim „na pamięć”, czyli (Łuksza umiejętnie wygrywa uruchomioną kontekstowo dwuznaczność tego sformułowania) bezrefleksyjnie, intuicyjnie, ale też w kierunku, w stronę pamięci i tego, co minione („na pamięć” jak np. na Berdyczów). Natura staje się depozytariuszką upodrzędnionej przeszłości. Oczywiście - tak jak w romantyzmie - potrzebny jest jeszcze poeta, który o tym opowie, przywróci czasoprzestrzenną jedność, zniweluje, choćby dokonało się to tylko $\mathrm{w}$ obrębie jednego tekstu, podział na naturę i kulturę, pamięć i historię: świat na co dzień ukryty, niewidoczny, niemy zostaje „światem przedstawionym". Ta zakonserwowana przeszłość, niczym skamielina oczekująca archeologa, może stać się kiedyś, jak to określa Ricoeur, przedmiotem pracy historii. Ta bowiem potrzebuje właściwego momentu, np. politycznego. "Zapomnienie" można więc traktować jako formę ochrony przeszłości, zabezpieczającą ją przed wydaniem na pastwę aktualnych animozji, emocji, roszczeń, koniunktury.

Ambiwalencje pamięci i zapominania oddaje żywioł wody - „Lethe, bogini zapominania [...] odpowiada wyobrażenie podziemnej rzeki. Ona z kolei dostarcza kategorii przepływu i upłynniania jako pojęć kluczowych dla metafory zapominania" ${ }^{26}$, jak czytamy np. u Butzera. Znaczące wydaje się w tym momencie samo wyeksponowanie przez Łukszę w tytule zbioru etymologii nazwy miasta - „Biały stok”, pisany osobno. I chodzi tu, co poetka pod-

\footnotetext{
25 A. Assmann, Metafory, modele i media pamięci, s. 112.

26 G. Buzter, Metaforyka pamięci, s. 206.
} 
kreślała w jednym z wywiadów, nie o stok-górę, tylko stok-strumień (taka wykładnia słowa "stok" odpowiada też oczywiście legendzie o założeniu miasta przez litewskiego kniazia Giedymina nad wyjątkowo czystym i urokliwym strumieniem). Zapominanie mogłoby być zatem jednym z rysów charakterystycznych "Młodego miasta”, które „dojrzewa, jak buza, / bulgot wielogłosy, palimpsest min / i gestów ciał jednorazowego użytku" (wiersz Rynek Kościuszki) ${ }^{27}$. Jednak

W świecie starożytnym obraz picia wody był powiązany zarówno z zapominaniem, jak i przypominaniem. Podobnie ambiwalentne znaczenia ma sama woda [wyróżn. A.A.]: Leta jest rzeką, która zabiera wszystko na zawsze, oddzielając nas tym samym od wcześniejszych etapów życia, tak jak Styks, który oddziela nas od życia ziemskiego. Wody życia i pamięci mają jednak wspólny początek. Kastalia, święte źródło wyroczni delfickiej, była w czasach rzymskich uważana za źródło poezji, jej wody zaś nieść miały moc przepowiadania przyszłości, zacierając tym samym granice między przepowiednią a pamięcią. Poeci głoszą światu to, co zostało im podarowane przez Muzy - córki Pamięci ${ }^{28}$.

Dzieje się tak zwłaszcza wtedy, gdy z wodą miesza się krew, tak jak w cytowanym opowiadaniu Прот, народжаны $\breve{y}$ верасьні [Prot, urodzony we wrześniu]. Sięgnijmy ponownie po mit: chcąc dowiedzieć się, jaki czeka go los, Odyseusz schodzi do Hadesu, by porozmawiać z Tejrezjaszem. „Umarli, których spotyka na swojej drodze [...], są niemi i wraz z utratą mowy tracą także pamięć" ${ }^{29}$. Zostanie im chwilowo przywrócona, gdy napiją się krwi owiec. W podziemnych rzekach Białegostoku, z których mieszkańcy czerpią pitną wodę, krąży krew Prota, dając szansę na odzyskanie pamięci tym, którzy tracą ją, przekraczając rogatki miasta: problem samopolonizacji, odcinania się od wiejskiej, białoruskiej przeszłości jest jednym z kluczowych tematów twórczości podlaskich Białorusinów.

Jak już wspomniano, ważnym „aktorem” - w rozumieniu Bruno Latoura $^{30}$ - procesów pamięci są u Łukszy rośliny. Odnajdziemy tu oczywiście klasyczne ludowe antropomorfizacje, rośliny empatyczne, współodczuwające, płaczące, ale nie tylko. Jak tłumaczy dziadek Lucynce, nie powinna współczuć dębowi, że został wyrzucony na pobocze jak śmieć, bo drzewo też nie „żałuje” ludzi z powodu tego, że żyją tak krótko czy nie widzieli tego wszystkiego, co ono. Podstawowym atrybutem roślin jest więc trwanie,

\footnotetext{
27 M. Luksza, Biały stok, s. 13.

28 A. Assmann, Metafory, modele i media pamięci, s. 116-117.

29 Tamże, s. 117.

30 Zob. B. Latour, Przedmioty także posiadaja sprawczość, przeł. A. Derra, w: Teoria wiedzy o przeszłości na tle wspótczesnej humanistyki.
} 
to, że są, można się na nie natknąć, potknąć, stawiają opór - robotnicy tępią na martwym już przecież dębie piły, łamią siekiery. Nawet jeśli nie będzie już innych śladów po ludzkich siedzibach, ich obecność zdradzi specyficzna roślinność - ten temat porusza w Drodze 816 (Białystok 2015) Michał Książek, na przykład wymieniając chwasty, które rosną wyłącznie na śmietnikach, albo odnajdując w leśnej głuszy resztki sadów; z tego samego powodu Łuksza wylicza wszystkie gatunki, jakie rosną na wyspie ${ }^{31}$. Poetka ma też w swoim dorobku wiersz Sad:

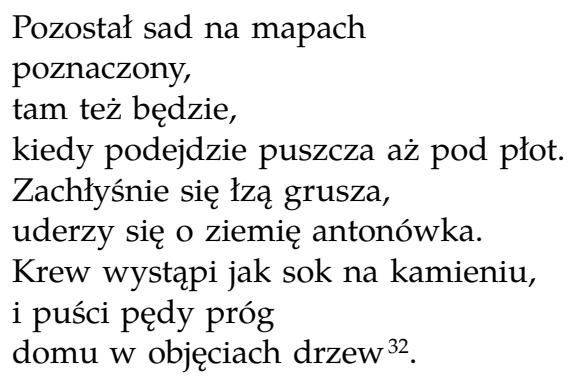

Warto $\mathrm{w}$ tym momencie przywołać pointę rozmowy $\mathrm{z}$ innym białoruskim pisarzem, Michałem Androsiukiem. Zapytany o to, co myśli na temat przyszłości Białorusinów, odpowiedział:

MA: Ja w ogóle o tym nie myślę. [...] Ja sadzę drzewa. Pinus aristata, sosna oścista amerykańska, która może żyć 5000 lat. Sądząc po jej wzroście, ma ich teraz jakieś 10, także jeszcze około 5000 przed nią. Nie będzie mnie, nie będzie naszej Europy, naszych książek itd., a ta sosna będzie.

DZ: Ale myśli Pan, że ona będzie pamiętała, że ją posadził Pan, pisarz polsko-białoruski?

MA: Nie. Ale ktoś pomyśli: skąd tu się wzięła taka sosna, która jest jedyna w całej okolicy. [...] Więcej takich sosen tu nie $\mathrm{ma}^{33}$.

31 Warto w tym momencie przywołać tekst Marzeny Zwierowicz mówiący o tym, że zieleń jej rodzaj, miejsca i struktura zasadzeń (fakt, że inne rośliny sadzono przy drodze, inne i w specyficzny sposób wokół kościoła, na cmentarzach, sadach i ogródkach przydomowych) stanowi istotny element krajobrazu odziedziczonego, co więcej, często trwalszy niż wytwory człowieka sensu stricto. M. Zwierowicz, Warmia i Mazury - krajobraz odziedziczony, w: Czas przekraczania granic. Antologia Borussi 1990-2015, red. I. Liżewska, K. Brakoniecki, R. Traba, Warszawa 2015.

32 M. Łuksza, Biały stok, s. 40-41.

${ }^{33}$ M. Androsiuk, Więcej takich sosen tu nie ma, z Michałem Androsiukiem rozm. E. Dąbrowicz, K. Sawicka-Mierzyńska, D. Zawadzka, w: Sokrat Janowicz - pisarz transgraniczny, Studia, wspomnienia, materiały, red. G. Charytoniuk-Michiej, K. Sawicka-Mierzyńska, D. Zawadzka, Białystok 2014, s. 423. 
Wobec krajobrazów, które noszą w sobie zarówno ryt zapomnienia, jak potencjał pamięci, odpominania, adekwatne wydaje się, użyte za Sokratem Janowiczem, określenie "zapomnieliska" (to tytuł jednego ze zbiorów jego miniatur) - można je potraktować jako odmianę zaproponowanej przez Rybicką kategorii „miejsc wydrążonych z pamięci”. Jak wynika z dokonanej przez Duć-Fajfer szczegółowej analizy etymologii tego neologizmu, mającej swoje źródło w kilku językach, w białoruskim i ukraińskim funkcjonują słowa oznaczające miejsce po czymś, np. церквішча - miejsce po cerkwi.

Myślenie w co najmniej dwóch językach [...] pozwala Janowiczowi skontaminować pamięć $\mathrm{z}$ niepamięcią $\mathrm{w}$ koegzystencji z miejscami, wobec których pamięć musi ustanowić się powinnościowo, stać się "czuwającą" czy wręcz kreującą.

[...] zapomnieliska to takie miejsca (konkretne i symboliczne), które każą pamiętać o czymś zapomnianym, zaniechanym, wyrugowanym, zastąpionym czymś innym, a stanowiącym bazę, coś podstawowego i esencjonalnego dla danej kultury i tożsamości ${ }^{34}$.

W twórczości Łukszy jedną z ich ważniejszych reprezentacji stał się topos Atlantydy.

Na najwyższym poziomie ogólności podziemiem tej krainy - krainy poezji Łukszy, ale też Podlasia - zalanym, jak to ujęła autorka we wstępie do Wierszy tutejszych, przez niepamięć - jest Wielkie Księstwo Litewskie. To nasza Atlantyda, zmitologizowane, idealne królestwo, które zgubiła pycha. Oczywiście celebrujemy, a nawet hołubimy jego historię, co nie znaczy, że tę samą (pisząc „my” mam na myśli Polaków), do której sięga Łuksza. Dla niej jest to przede wszystkim czas sprzed podpisania unii brzeskiej, kiedy ruski był równoprawnym językiem urzędowym, a bycie "Polakiem” miało bardziej obywatelski niż etniczny charakter. Specyficzny, wydobyty poetycko spośród urokliwych podlaskich pejzaży krajobraz staje się nośnikiem konkretnej przeszłości. Takie myślenie o krajobrazie ma oczywiście romantyczną proweniencję. Jak pisze Alina Witkowska:

Wszelkie [...] romantyczne przeświadczenia o narodzie, o jego charakterze i duchu, za podstawę brały tyleż naturę, co kulturę, tyleż przeszłość, co współczesność, tyleż świadectwa postrzegane, co prawdy ukryte. Krajobraz łączył wszystkie te czynniki, różne sposoby istnienia w czasie, i dlatego w rękach romantyka stawał się niezastąpioną wykładnią ducha narodu.

[...] szczególnie dobrane obiekty natury mogły poświadczać także ducha dziejów narodu, obecnym czynić to, co już dawno w przeszłość odeszło, a co było bardziej bezpośrednią i czystą, na miarę tamtych czasów, manifestacją istoty

34 H. Duć-Fajfer, Pomiędzy bukwa a litera, s. 141, 142. 
narodu. Mogły więc „uobecniać” przeszłość. Człowiek współczesny odnajdywał w ten sposób zagubiony kontakt z własną przeszłością, pokonywał wyobcowanie i zagubienie, restytuował continuum duchowego trwania ${ }^{35}$.

Przekładając to na obrazy z twórczości Miry Łukszy, można powiedzieć, że Pryszcz i jego przyjaciele jeżdżą rokrocznie na Siemianówkę, by „restytuować continuum duchowego trwania" i nie skończyć we łzach na białostockim bruku, jak inicjujący opowiadanie staruszek, prawdopodobnie (tak nakazywałaby logika opowieści) wysiedlony z jednej z zalanych wsi. Oczywiście - i Łuksza ma tego świadomość - człowiek nie może żyć wyłącznie przeszłością, tak jak nie potrafi przebywać długo pod wodą. Dlatego, trochę na kształt Mickiewiczowskiego ptaka-ryby, zanurza się w niej tylko na chwilę, wstrzymując oddech. Całkowite pogrążenie się w tym, co minione, oznaczałoby śmierć.

\section{The Figure of Atlantis in Mira Łuksza's Writings}

\section{Summary}

The article offers a reading of a poet and author Mira Łuksza, who was born in 1958 and lives in the region of Podlasie. Atlantis appears to be a visible recurring motif in her writings. It symbolizes the underwater world and becomes the point of departure for further interpretations. Finally, it prompts the questions of remembering, forgetting and identity in the context of Polish-Belarusian borderland.

Keywords: Atlantis, Polish-Belarusian borderland, Podlasie, identity, memory, Mira Łuksza

35 A. Witkowska, Stawianie, my lubim sielanki..., Warszawa 1972, s. 132, 133. 